\section{Toward greater inclusion: lessons from Peru in confronting challenges of multi-sector collaboration}

\author{
Anne L. Buffardi, ${ }^{1}$ Robinson Cabello, ${ }^{2}$ \\ and Patricia J. Garcia ${ }^{3}$
}

Suggested citation: Buffardi AL, Cabello R, Garcia PJ. Toward greater inclusion: lessons from Peru in confronting challenges of multi-sector collaboration. Rev Panam Salud Publica. 2012;32(3):245-50.

\section{SYNOPSIS}

Despite widespread enthusiasm for broader participation in health policy and programming, little is known about the ways in which multi-sector groups address the challenges that arise in pursuing this goal. Based on the experience of Peru's National Multi-sector Health Coordinating Body (CONAMUSA), this article characterizes these challenges and identifies organizational strategies the group has adopted to overcome them. Comprising nine government ministries, nongovernmental organizations, academia, religious institutions, and international cooperation agencies, CONAMUSA has faced three principal challenges: 1) selecting representatives, 2) balancing membership and leadership across sectors, and 3) negotiating role transition and conflict. In response, the group has instituted a rotation system for formal leadership responsibiliti es, and professionalized management functions; created electoral systems for civil society; and developed conflict of interest guidelines. This case study offers lessons for other countries trying to configure multi-sector groups, and for donors who mandate their creation, tempering unbridled idealism toward inclusive participation with a dose of healthy realism and practical adaptation.

Key words: social participation; health policy, planning and management; non-governmental organizations; public sector; leadership; Peru.

\footnotetext{
1 Evans School of Public Affairs, University of Washington, Seattle, United States of America. Send correspondence to: Anne L Buffardi, buffardi@uw.edu

2 NGO Vía Libre, Lima, Peru.

3 Unidad de Epidemiología, ITS y VIH, Facultad de Salud Pública y Administración "Carlos Vidal Layseca," Universidad Peruana Cayetano Heredia, Lima, Peru.
}

Calls for broader participation in health policy and programming resound throughout the global health arena. Efforts to meet this challenge have taken various forms. The Health Agenda for the Americas, launched in Panama City in June 2007, promotes "social participation, the opportunity for all of society to participate in defining and carrying out public health policies and assessing their outcomes" (1). Some international donors, such as the Global Fund to Fight AIDS, Tuberculosis and Malaria (GFATM), and the GAVI Alliance (formerly the Global Alliance for Vaccines and Immunisation), now mandate the participation of multi-stakeholder groups in health programs as a condition of their funding (2). Peru's National Multi-sector Health Coordinating Body (Coordinadora Nacional Multisectorial en Salud, CONAMUSA), which comprises nine government ministries, nongovernmental organizations (NGOs), academia, religious institutions, and international cooperation agencies, is another example of greater movement toward multi-sector collaboration. While the trend toward broader inclusion in health sector policy-making and program planning provides a great opportunity to expand the participation of nonhealth ministries as well as civil society, ${ }^{4}$ it also raises new challenges not confronted by single-sector, stategoverned health programs.

\section{PARTICIPATORY POLICY-MAKING AND PLANNING: POTENTIAL BENEFITS AND LIMITATIONS}

The use of multi-stakeholder groups in decisionmaking has been lauded for reasons of effectiveness, efficiency, and equity. Involving those most familiar with the issues targeted by prospective interventions and the local context can lead to more effective project designs that better fit community needs and help facilitate implementation by increasing local support, legitimacy, and transparency, thus improving efficiency and long-term sustainability (3-6). Multi-stakeholder participation can also lead to greater equity in the process of decision-making $(7,8)$. On the other hand, critics argue that focusing on the inclusion of individuals in policy-making and programming activities neglects the broader social structure within which these types of decisions are made, ignores the costs of their

\footnotetext{
4 In this article, the term "civil society" is used in a broad sense, meaning "non-state actors." In terms of representation within CONAMUSA, a further distinction is made among four types of non-state actors: civil society associations, NGOs, academic institutions, and religious institutions, with the former category composed largely (if not exclusively) of members of distinct population groups (e.g., people living with HIV/AIDS, and lesbian, gay, bisexual, and transgender communities).
} 
participation, and overlooks power dynamics, which can replicate inequalities across and within subpopulations. Use of a joint decision-making approach to enhance managerial effectiveness has been criticized as a means of co-opting empowerment language to improve acceptance of externally imposed policies rather than effect structural change (9-14).

Whether enthusiastic or critical, previous research on participatory approaches to policy-making and programming is largely theoretical or normative, offering few examples of how to address the costs of expanded participation and confront power imbalances in order to reap the potential benefits of greater inclusion. While some studies have identified characteristics associated with "effective" collaborations, such as inclusive representation, strong leadership, clear communication, transparent operations, and well-defined responsibilities (15-19), little has been published on how to shape organizational structures to achieve these abstract goals. The current study aimed to help fill this gap, using the experiences of Peru's multi-sector health coordinating body (CONAMUSA) as a case study. ${ }^{5}$ This article describes the three main challenges faced by CONAMUSAselecting representatives, balancing membership and leadership across sectors, and negotiating role transition and conflict-and the organizational strategies the group adopted to address them.

\section{THE CASE OF CONAMUSA}

CONAMUSA was created in 2002 in response to feedback on Peru's first proposal to GFATM, which cited the lack of a multi-sector coordinating body as a major reason the proposal was not funded. As quoted in an early case study of Peru's country coordinating mechanism (CCM), "On the basis of this obligation imposed by the Global Fund, [people from multiple sectors] entered into a dialogue that never before took place in the writing of a national proposal" (22). Members of the new coordinating entity were diverse: high-ranking officials representing nine government ministries (Health, Education, Interior, Woman and Social Development, Labor, Foreign Relations, Defense, Economy and Finance, and Justice), and representatives of NGOs, academia, religious organizations, international development agencies, and associations of individuals affected by and vulnerable to HIV, tuberculosis (TB), and malaria. The breadth of participation in CONAMUSA is widely considered unprecedented in Peru and has created new opportunities for cross-sector dialogue and activities $(18,23$, 24): "The collaborative, multi-sectoral work is quite rich because it has enabled awareness of distinct reali-

\footnotetext{
This study emerged out of a larger, comparative case study of bilateral and multilateral donors in Peru's health sector that identified various patterns in donor-recipient relationships. CONAMUSA was the only example of a decision-making structure that formally involved government, NGOs, and civil society associations (20). As such, it met the defining criteria of a "crucial" case (21), enabling the authors to examine the dynamics of multi-sector collaboration over time.
}

ties and visions around the same issue." ${ }^{6}$ The group's role is not to communicate and coordinate separate activities of individual members; rather, they are responsible for tangible outputs requiring joint effort, including the development and oversight of country grant proposals. In this sense, they could be better characterized as a governance body than a coordinating mechanism.

In terms of financial and policy outcomes, CONAMUSA has been extremely productive. The group has secured nearly US \$140 million in GFATM funding, an amount second only to Haiti in all of Latin America. CONAMUSA members guided the creation of national multi-sector strategic plans for HIV and other sexually transmitted infections (STIs) (20072011), and TB (2010-2019). One of the most notable achievements is expanded access to HIV treatment: four years into the group's tenure, the Peruvian government began its program of free, universal access to highly active antiretroviral therapy (HAART).

To identify CONAMUSA's organizational challenges and response strategies, the authors of this study conducted semi-structured interviews with 46 purposively selected key informants: current and former members of CONAMUSA and the Executive Secretariat, national and regional government officials, GFATM implementation staff and management, and beneficiaries and community activists. Interviewees included 21 officials from the public sector, 1 from an international governmental organization, 12 from NGOs, 7 from civil society associations, and 5 members of the community (direct beneficiaries and community activists). Interviews were conducted in person and lasted approximately one hour. Evaluations and transcripts of the audio-recorded interviews were coded according to challenges identified in the literature (costs of participation and group power dynamics) and new codes were created based on additional challenges articulated by CONAMUSA members, namely those relating to representation, role definition, and conflict. In addition to primary data collection, the authors conducted a document review of internal and external evaluations of CONAMUSA and Peru's GFATM programs.

\section{Challenges and response strategies}

Since its inception, CONAMUSA has faced three principal challenges: 1) selecting representatives, 2) balancing membership and leadership across sectors, and 3) negotiating role transition and conflict. Table 1 summarizes how each challenge has been manifested and the strategies the group has adopted in response, which include sharing formal leadership responsibilities, and professionalizing management functions; creating electoral systems for civil society; and developing conflict of interest guidelines.

\footnotetext{
Guevara S, Cisneros R, Burgos H. Sistematización de la experiencia de la CONAMUSA [unpublished report]. Lima; 2009.
} 
TABLE 1. Challenges of multi-sector collaboration faced by Peru's National Multi-sector Health Coordinating Body (Coordinadora Nacional Multisectorial en Salud, CONAMUSA) and corresponding organizational strategies adopted in response, Lima, Peru, 2002-2010

\begin{tabular}{|c|c|c|}
\hline Challenges & Manifestation in practice & Organizational strategies adopted in response \\
\hline Selecting representatives & $\begin{array}{l}\text { Dominance of representatives from more } \\
\text { organized, well-established civil society groups }\end{array}$ & $\begin{array}{l}\text { Instituted formal voting process to elect representative of } \\
\text { affected populations, rather than decision by assembly }\end{array}$ \\
\hline $\begin{array}{l}\text { Balancing membership and } \\
\text { leadership across sectors }\end{array}$ & $\begin{array}{l}\text { Dominance of Ministry of Health relative to } \\
\text { other government ministries and non-state } \\
\text { sectors }\end{array}$ & $\begin{array}{l}\text { - Created Vice Chair position and passed rotation policy to } \\
\text { alternate Chair position between state and non-state members } \\
\text { - Hired full-time Executive Secretary and administrative staff after }\end{array}$ \\
\hline & Allocation of seats by sector and disease & $\begin{array}{l}\text { - Allocated two seats for HIV representatives, one each for } \\
\text { tuberculosis and malaria } \\
\text { - Requested separate representatives for sex workers, gay } \\
\text { communities, and transgender communities }\end{array}$ \\
\hline \multirow[t]{2}{*}{$\begin{array}{l}\text { Negotiating role transition } \\
\text { and conflict }\end{array}$} & $\begin{array}{l}\text { Between oversight and implementation: } \\
\text { NGO representatives whose organizations } \\
\text { implement projects }\end{array}$ & - Developed formal conflict of interest policy \\
\hline & $\begin{array}{l}\text { Between implementation and activism: } \\
\text { civil society representatives }\end{array}$ & $\begin{array}{l}\text { Continued advocacy efforts by civil society groups outside of } \\
\text { CONAMUSA who chose not to serve as CONAMUSA members } \\
\text { or Global Fund implementing agents }\end{array}$ \\
\hline
\end{tabular}

Selecting representatives. While government election and appointment processes are well established, no analogous mechanisms exist for civil society. CONAMUSA's selection methods varied by group: delegation for government members; election for NGOs and representatives of populations affected by $\mathrm{HIV}, \mathrm{TB}$, and malaria; nomination by assembly for representatives of vulnerable populations; and self-expressed interest for academic and religious institutions (25).

Smaller organizations have criticized the tendency for more established NGOs and civil society associations to be selected as CONAMUSA members and GFATM implementing agents, and called for more varied representation. As one member noted: "It is essential that there be rotation among civil society representatives; it is good to give the opportunity to new actors." 6 To address these concerns, associations of people living with HIV / AIDS (PLWHA) instituted a democratic voting process. Through CONAMUSA, they created an electoral committee of representatives from the Ministry of Health, civil society, and an international development agency to oversee a national secret ballot election, with 66 accredited PLWHA associations participating.

Balancing membership and leadership across sectors. CONAMUSA was initially led solely by a Chair, who from the outset has been the Minister of Health. In 2008, using GFATM funds, CONAMUSA hired a small technical team, headed by an Executive Secretary, to handle day-to-day management functions. To balance leadership opportunities between state and non-state actors, they added a Vice Chair, who must represent a different sector than the Chair. CONAMUSA has also passed, but to date has not yet instituted, a policy whereby the Chair position alternates between sectors.

To ensure participation from populations affected by each disease, CONAMUSA allocates two seats to PLWHA, and one each for people living with TB and malaria. The disparity in representation across the different disease groups reflects the level of mobilization among the subpopulations affected by each one. Within the context of Peru's concentrated HIV epidemic, there is a diverse set of well-organized PLWHA associations. TB affects a greater number of individuals, but they are more dispersed and less organized as a group compared to PLWHA.

CONAMUSA also allocates one seat to represent populations most vulnerable to HIV acquisition. With just one representative, people in the transgender community, female sex workers, and gay men have voiced concerns about the homogenization of their unique identities and requested separate representation. As one activist explained, "We should have a direct voice in CONAMUSA. We don't need intermediaries because we are not second-class citizens." Others have questioned how to best balance inclusiveness with manageability in terms of group size. As one person said: "I honestly think we could take a bigger step in enabling this participation, ... but at the same time we can't say yes to everyone."

While many civil society groups are eager to engage in CONAMUSA's decision-making processes, their participation has a cost. For representatives whose involvement is not part of full-time employment, CONAMUSA represents a significant time investment. Some have noted the challenges of creating an entity where all voices are truly considered equal. As one interviewee said: "I think some technocrats have imagined the participation of populations [affected by/vulnerable to HIV] without contextualizing the effective weight of exclusion and vulnerability [they face in society]. ... I think that the difficulties or limits of these [multi-sector] projects are in their inability to interact with existing social and political processes." 
Negotiating role transition and conflict. To meet CONAMUSA's requirements for multi-sector representation, its members often serve in multiple capacities and thus experience conflict in terms of their roles in oversight, implementation, and activism. For example, several CONAMUSA members work for NGOs and civil society associations that are implementing GFATM projects. Some civil society associations have also experienced mission conflict as their relationship with the state has shifted from activist to partner. As one member explained: "When there weren't any multi-sector [processes], people needed to stand outside the Ministry's door banging pots and making noise so they would know that we had needs and they needed to make a change. ... Now, as they say, this [activism] has been lost ... because we are too immersed in the process. ... I understand it is important to be in decision-making [groups] . . . but civil society must also exercise its role as watchdog. ... I think it is important to do both things; what we have to strengthen is the demarcation [between roles]."

In addition, as observed in various research assessments, some civil society organizations have experienced a loss of social capital resulting from role conflict and competition for funding $(23,26)$. Some groups have chosen not to participate in CONAMUSA or GFATM implementation activities to preserve the integrity of their external advocacy role.

To address these problems, CONAMUSA has developed a conflict of interest guide that stipulates that its members cannot work for organizations implementing GFATM projects. While this policy helps prevent conflict of interest by delineating roles more clearly, it also prevents potential members with considerable expertise from participating. In addition to formal regulations, reducing conflicts of interest requires self-awareness on the part of the members. As one member noted: "For myself, I am clear that each time we address a topic that involves my organization, I don't participate."

\section{LESSONS LEARNED}

The case of CONAMUSA provides evidence that broadening participation can expand access to decision-making processes and health care, particularly for stigmatized populations. At the same time, configuring representative and balanced participation of multi-sector coalitions is complex and poses disproportionate costs of time and potential role conflict for civil society members. The CONAMUSA case also offers two key lessons for groups aiming to expand participation: the importance of institutionalizing participation mechanisms and health policy reforms, and the influence of civil society mobilization.

To foster the division of power, CONAMUSA modified its organizational structure to include a Vice Chair, revised membership eligibility to protect against conflicts of interest, and created electoral systems for civil society. The institutionalization of these mechanisms to balance leadership and select representatives ensures that the group's commitment to inclusive participation endures beyond the involvement of specific individuals. Similarly, the creation of multiyear strategic plans for HIV and other STIs, and $\mathrm{TB}$, and the passage of legislation guaranteeing access to treatment, codifies CONAMUSA's work into national health policy that will last beyond the tenure of a single administration.

The case of CONAMUSA highlights the importance of mobilization in terms of facilitating civil society involvement in multi-sector groups, as shown by the difference between active PLWHA and lesbian, gay, bisexual, and transgendered (LGBT) movements and the more dispersed, less organized communities of people living with TB and malaria. Groups that are well organized to articulate their interests have been able to influence both the structure and the agenda of CONAMUSA by advocating for specific policy changes, greater leadership opportunities, and greater representation.

The experience of CONAMUSA also suggests that donor-mandated participation can elevate previously marginalized voices and foster cross-sector interaction. The relatively large size of LGBT and PLWHA movements in Peru has enabled some groups to engage in decision-making and service delivery while others maintain an external activist role. However, external imposition of multi-sector coalitions in contexts without a diverse set of mobilized groups may pose risks to civil society's role as a watchdog or agent of change, and may further marginalize these communities by implying inclusion when it does not truly exist.

Thus, the level of civil society engagement, which varies substantially across the Americas, should determine where this model is applied. In addition, when civil society is formally involved in multi-sector decision-making, selection of its representatives should be determined by the group's mandate. For example, if the aim is to expand inclusion of populations affected by specific diseases, civil society representatives should be drawn from subpopulations vulnerable to and living with those diseases, as is the case with CONAMUSA. If the aim is to expand geographic diversity, representatives should reside outside of the capitol city. Subpopulations should be specifically named (e.g., PLWHA) and represented separately rather than through one member deemed representative of multiple groups.

It is important to note that in the case of CONAMUSA, these organizational strategies arose within the context of an enormous external financial incentive, sustained economic growth, and the support of the six Ministers of Health who have served during the group's tenure. In addition, while CONAMUSA's agenda and structure have been driven by the members themselves, the opportunity for cross-sector decision-making would not likely have existed without the donor requirement. This observation suggests that the engagement of more powerful actors-government in the case of CONAMUSA-may require strong external incentives. Moving forward, one of CONAMUSA's greatest challenges will be sustaining the group when external funding declines. 


\section{Conclusion}

The CONAMUSA case illustrates the dual benefits and complexities of a participatory approach as a new decision-making model in the health sector. It provides evidence that conditions may make this model more feasible, and specific operational strategies and broader lessons regarding the institutionalization of practices. For other countries trying to configure multi-sector groups, and donors who mandate their creation, the CONAMUSA experience helps to temper the often unbridled idealism toward inclusive participation with a dose of healthy realism and practical adaptation.

Funding. This work was supported through a Thomas Francis Jr. Global Health Fellowship through the University of Washington and by the Global Health Demonstration Program in Peru (U.S. National Institutes of Health Fogarty Framework Programs for Global Health grant \#R25TW007490).

Author contributions. ALB conceptualized and conducted the study, analyzed the data, and drafted the manuscript. RC assisted with the interpretation of the data and helped to revise the manuscript. PJG helped to conceptualize the study, assisted with the interpretation of the data, and revised the manuscript.

Conflict of interest. RC served as the HIV NGO representative on CONAMUSA from 2002-2009 and as the Vice Chair from 2005-2009. PJG has served on CONAMUSA as the academic representative since 2002. The authors have no commercial conflicts of interest to declare.

Acknowledgments. The authors would like to thank Pablo Anamaria; the current and former members of CONAMUSA; Mary Kay Gugerty and Joe Zunt at the University of Washington; and all of the informants, for sharing their insights and expertise.

\section{SINOPSIS}

\section{Hacia una mayor inclusión: enseñanzas del Perú para afrontar los retos de la colaboración multisectorial}

A pesar del entusiasmo generalizado por la mayor participación en las políticas y programas sanitarios, poco se sabe sobre las formas de afrontar los retos que se plantean en la consecución de este objetivo por parte de los grupos multisectoriales. Este artículo parte de la experiencia de la Coordinadora Nacional Multisectorial en Salud del Perú (CONAMUSA) para caracterizar dichos retos e identificar las estrategias de organización que ha adoptado el grupo a fin de superarlos. CONAMUSA, formada por nueve ministerios del gobierno, organizaciones no gubernamentales, instituciones académicas, organizaciones religiosas y agencias de cooperación internacional, se ha enfrentado con tres retos fundamentales: 1) elegir a los representantes, 2) encontrar el equilibrio entre la representación de los miembros y el liderazgo en los distintos sectores y 3) negociar el cambio de roles y los conflictos. Para responder a estos retos el grupo ha establecido un sistema rotatorio para las responsabilidades formales de liderazgo y ha profesionalizado las funciones de gestión, se han creado sistemas electorales para la sociedad civil y se han elaborado pautas para los conflictos de intereses. Este estudio de casos aporta lecciones para otros países que estén tratando de configurar grupos multisectoriales, así como para los organismos de ayuda que dirigen su creación, suavizando los idealismos extremos con una dosis de realismo saludable y de adaptación práctica para lograr una participación inclusiva.

Palabras clave: participación social; políticas, planificación y administración en salud; organizaciones no gubernamentales; sector público; liderazgo; Perú.

\section{REFERENCES}

1. Pan American Health Organization. Health Agenda for the Americas 2008-2017. Presented by the Ministers of Health of the Americas in Panama City, June 2007. Washington: PAHO; 2007. Available from: http://new.paho. org/hq/dmdocuments/2009/Health. Agenda_for_the_Americas_2008-2017. pdf

2. Biesma RG, Brugha R, Harmer A, Walsh A, Spicer N, Walt G. The effects of global health initiatives on country health systems: a review of the evidence from HIV/AIDS control. Health Policy Plan. 2009;24(4):239-52.

3. Mazmanian DA, Sabatier PA. Implementation and public policy. Glenview, IL: Scott, Foresman; 1983.
4. Chambers R. Whose reality counts? Putting the first last. London: ITDG Publishing; 1997.

5. Brinkerhoff DW, Crosby BL. Managing policy reform: concepts and tools for decision-makers in developing and transitioning countries. Bloomfield, CT: Kumarian Press; 2002.

6. Gibson CC, Andersson K, Ostrom E, Shivakumar S. The Samaritan's dilemma: the political economy of development aid. Oxford: Oxford University Press; 2005.

7. Uvin P. Human rights and development. Bloomfield, CT: Kumarian Press; 2004.

8. Sen A. Development as freedom: New York: Knopf; 1999.
9. Cleaver F. Paradoxes of participation: questioning participatory approaches to development. J Int Dev. 1999;11(4):597-612.

10. Mansuri G, Rao V. Communitybased and driven development: a critical review. World Bank Res Obs. 2004;19(1):1-39.

11. Cooke B, Kothari U, editors. Participation: the new tyranny? London: Zed Books; 2001.

12. Howell J, Pearce J. Civil society: technical instrument or social force for change? In: Lewis D, Wallace T, editors. New roles and relevance: development NGOs and the challenge of change. Bloomfield, CT: Kumarian Press; 2000. Pp. 75-87. 
13. Cornwall A. Unpacking 'Participation': models, meanings and practices. Community Dev J. 2008;43(3):269-83.

14. Blair H. Civil society, empowerment, democratic pluralism and poverty reduction: delivering the goods at national and local levels. In: Lewis D, Wallace $\mathrm{T}$, editors. New roles and relevance: development NGOs and the challenge of change. Bloomfield, CT: Kumarian Press; 2000. Pp. 109-19.

15. SpicerN, AleshkinaJ,Biesma R, Brugha R, Caceres C, Chilundo B, et al. National and subnational HIV/AIDS coordination: Are global health initiatives closing the gap between intent and practice? Global Health. 2010;6(1):3.

16. Zafar Ullah AN, Newell JN, Ahmed JU, Hyder MKA, Islam A. GovernmentNGO collaboration: the case of tuberculosis control in Bangladesh. Health Policy Plan. 2006;21(2): 143-55.

17. Grundy J. Country-level governance of global health initiatives: an evaluation of immunization coordination mechanisms in five countries of Asia. Health Policy Plan. 2010;25(3): 186-96.

18. Global Fund to Fight AIDS, Tuberculosis and Malaria. Lessons learned in the field: health financing and governance. A report on the Country Coordinating Mechanism Model. Global
Fund Implementer Series. Geneva: GFATM; 2008. Available from: www. theglobalfund.org/documents/ccm/ CCM_Global2008_Report_en/

19. Cornwall A, Lucas H, Pasteur K. Accountability through participation: developing workable partnership models in the health sector. IDS Bull-I Dev Stud. 2000;31(1):1-13.

20. Buffardi AL. Donor differentiation: patterns of donor-state relations among international development donors. Paper presented at the Annual International Studies Association Convention, Montreal, Canada, March 16-19, 2011. Available from: http:// citation.all academic.com $/ \mathrm{meta} / \mathrm{p} \_$mla apa_research_citation/4/9/8/8/4/ pages498848/p498848-1.php

21. Gerring J, Seawright J. Techniques for choosing cases. In: Gerring J, editor. Case study research: principles and practices. New York: Cambridge University Press; 2007. Pp. 86-150.

22. Collins J. Peru Country Coordinating Mechanism (CCM). Case study: December 9-18, 2003. Geneva: Global Fund to Fight AIDS, Tuberculosis and Malaria; 2003.

23. Cáceres CF, Girón JM, Sandoval C, López R, Valverde R, Pajuelo J, et al. Implementation effects of GFATM-sup- ported HIV / AIDS projects on the health sector, civil society and affected communities in Peru 2004-2007. Glob Public Health. 2010;5(3):247-65.

24. Valverde R, Cabello R. Monitoring the implementation of the UNGASS Declaration of Commitment: country report-Peru. Lima: Organization Vía Libre; 2005.

25. Cáceres CF, López R, Pajuelo J, Vásquez P, Valverde R, Rosasco A, et al. Lessons learned from the implementation of the GFATM-supported HIV/AIDS projects in Peru. Selected findings: effects on the interactions between the state, NGOs, and $\mathrm{CBO}$ [PowerPoint presentation]. Lima: Universidad Peruana Cayetano Heredia. Available from: www.ghinet. org/downloads/Peru.ppt

26. Cáceres CF, Mendoza W. The national response to the HIV/AIDS epidemic in Peru: accomplishments and gaps-a review. J Acquir Immune Defic Syndr. 2009;51 Suppl 1: S60-6.

Manuscript received on 26 August 2011. Revised version accepted for publication on 8 March 2012. 